\title{
Correction: Abatacept in combination with methotrexate in Japanese biologic-naive patients with active rheumatoid arthritis: a randomised placebo-controlled phase IV study
}

Matsubara T, Inoue H, Nakajima T, et al. Abatacept in combination with methotrexate in Japanese biologic-naive patients with active rheumatoid arthritis: a randomised placebo-controlled phase IV study. RMD Open 2018;4:e000813.

The article has been corrected since it was published online.

In the Results section of the abstract (page 1), sentence 4 should read "Radiographic non-progression rates (change in vdH-mTSS $\leq$ smallest detectable change (1.9)) were $88.1 \%$ and $75.4 \%$ in abatacept and placebo groups, respectively."

In the "Radiographic assessment" paragraph of the Methods section (page 2), sentence three should read "The rate of radiographic non-progression at week 24, defined as the proportion of patients with a change from baseline vdH-mTSS $\leq 1.9$ (smallest detectable change (SDC) $),{ }^{20}$ was a secondary endpoint."

In the "Radiographic assessment" section of the Results (page 7, paragraph 2), sentence two should read "The radiographic non-progressor rates in the abatacept plus MTX group and the placebo plus MTX group were evaluated by the proportion of patients with change from baseline in vdH-mTSS below SDC (1.9), 0.5 or 0 at week 24 and week 52 (see online supplementary table S1).”

Open access This is an open access article distributed in accordance with the Creative Commons Attribution Non Commercial (CC BY-NC 4.0) license, which permits others to distribute, remix, adapt, build upon this work noncommercially, and license their derivative works on different terms, provided the original work is properly cited, appropriate credit is given, any changes made indicated, and the use is non-commercial. See: http://creativecommons. org/licenses/by-nc/4.0

(C) Author(s) (or their employer(s)) 2018. Re-use permitted under CC BY-NC. No commercial re-use. See rights and permissions. Published by BMJ.

RMD Open 2019;5:e000813corr1. doi:10.1136/rmdopen-2018-000813corr1

A) Check for updates 